\title{
Oak forests of the class Quercetea pubescentis in Central- Eastern Ukraine
}

\author{
Igor Goncharenko¹, Oleksii Kovalenko² \\ ${ }^{1}$ Institute for Evolutionary Ecology of NAS of Ukraine, 37 Academician Lebedev str., Kyiv, Ukraine, \\ 03143; goncharenko.ihor@gmail.com \\ ${ }^{2}$ National Museum of Natural History of NAS of Ukraine, 15B Khmelnytskoho str., Kyiv, Ukraine, \\ 01601
}

Goncharenko, I. \& Kovalenko, O. (2019): Oak forest of the class Quercetea pubescentis in Central-Eastern Ukraine. - Thaiszia - J. Bot. 29 (2): 191-215

\begin{abstract}
The article is devoted to the phytosociological study and vegetation classification of the dry-mesic oak forests in the central and eastern regions of Ukraine. We showed that oak forests of the Quercetea pubescentis class have specific northern features in the region and their syntaxonomic position at the level of alliances was not assigned. Syntaxa formed three distinct geographical groups eastward from the Dnieper lowland to the Middle Russian Upland. Ordination, phytoindication, and comparative floristic analysis with other syntaxa from adjacent regions were performed. New associations (Digitali grandiflorae-Quercetum roboris ass. nova and Carici praecocis-Quercetum roboris ass. nova) were reported. Two edaphic subtypes of dry-mesic oak forests (terrace and ravine oak forests) were distinguished and their floristic features were discussed.
\end{abstract}

Keywords: forest-steppe zone, Quercetea pubescentis, syntaxonomy, thermophilous oak forests, Ukraine.

\section{Introduction}

Thermophilous oak forests attracted attention of botanists due to the high level of biodiversity and a number of rare species. The centre of diversity of the Quercetea pubescentis class is located in southern Europe, the Mediterranean, and Asia Minor (Mucina et al. 2016). The origin of these forests is associated with the postglacial climatic optimum, and the current reduction of their area is 
considered to be a consequence of a human impact (Faliński \& Falińska 1986). In Europe, the range of thermophilous oak forests covers many countries: e.g. Poland (Jakubowska-Gabara 2000; Matuszkiewicz 2007; Kasprowicz 2010), Germany (Oberdorfer 1992), Austria (Mucina et al. 1993), Czech Republic (Chytrý \& Horák 1997; Chytrý 1997), Slovak Republic (Roleček 2004; Roleček 2005; Roleček 2007), Hungary (Zólyomi 1957; Zólyomi et al. 2013; Lendvai et al. 2014; Horváth et al. 2017), Serbia, Croatia (Čarni et al. 2009; Purger et al. 2014), Romania (Indreica 2011), Bulgaria (Tzonev et al. 2009), Bosnia and Herzegovina (Stupar et al. 2015).

Syntaxonomic position of thermophilous oak forest remains controversial in cool temperate regions, where there are significant floristic differences from the core (typical) sub-Mediterranean type. European authors emphasize the need for a pan-European revision of Quercetea pubescentis class (Mucina et al. 2016). In Eastern Europe, and especially in northern localities, the syntaxonomy of dry-mesic oak forests (in the region of research the term "dry-mesic" will be used hereinafter instead of the "thermophilous" forests) is even more unclear because these territories are very poorly explored. Authors who have studied dry-mesic oak forests in Western Russia in detail emphasize the differences from the related syntaxa from Central Europe (Semenishchenkov 2012; Bulokhov \& Semenishchenkov 2013). But, despite this, syntaxa from this territory have been controversially included by the authors in the Quercion petraeae Issler 1931, which is Central European alliance (Mucina et al. 2016). In Ukrainian publications, data on dry-mesic oak forests are not only incomplete, but also need to be synthesized. They are scattered over 5 alliances (Aceri tatarici-Quercion Zólyomi 1957, Quercion petraeae, Pino-Quercion Medwecka-Kornaś et al. in Szafer 1959, Genisto germanicae-Quercion Neuhäusl et Neuhäuslová-Novotná 1967, Convallario majalis-Quercion roboris Shevchyk et Solomakha 1996) and within three classes of vegetation - Carpino-Fagetea, Quercetea pubescentis, Quercetea robori-petraeae. Moving eastward, on the vast territory of the East European Plain, dry-mesic oak forests have not been studied with a large gap until the Southern Urals, where the easternmost locations are likely found and the alliance Lathyro pisiformis-Quercion roboris Solomeshch et Grigoriev in Willner et al. 2016 has been described (Martynenko et al. 2008; Mirkin et al. 2010; Willner et al. 2016). The issue is even more complicated, given that until the $80 \mathrm{~s}$ of the last century, forests of this type were overlooked due to the use of the dominant classification approach in the Soviet geobotanical school for a long time.

The aim of the study is to perform syntaxonomic and numerical analysis of the dry-mesic oak forests of the central and eastern parts of Ukraine, that is, in the territories from which still little actual data are available. Whether the dry-mesic forest of this territory belongs to a separate alliance remains an issue and cannot be resolved in this study. We will show the specifics of the communities of the class of Quercetea pubescentis in the remote northern location of its distribution range.The floristic comparative analysis will reveal the floristic features of the studied syntaxa and differences from other similar associations. Environmental factors affecting the floristic differentiation will be studied by superposition of the model of unconstrained ordination and data obtained by the phytoindication method. 


\section{Material and methods}

\section{Study region}

The study region (Fig. 1) is located in the central and eastern parts of Ukraine from the Dnieper valley in the west to the Middle Russian Upland in the east. It encompasses mainly the northern part of the forest-steppe zone and partially the southern part of the forest zone in Ukraine.

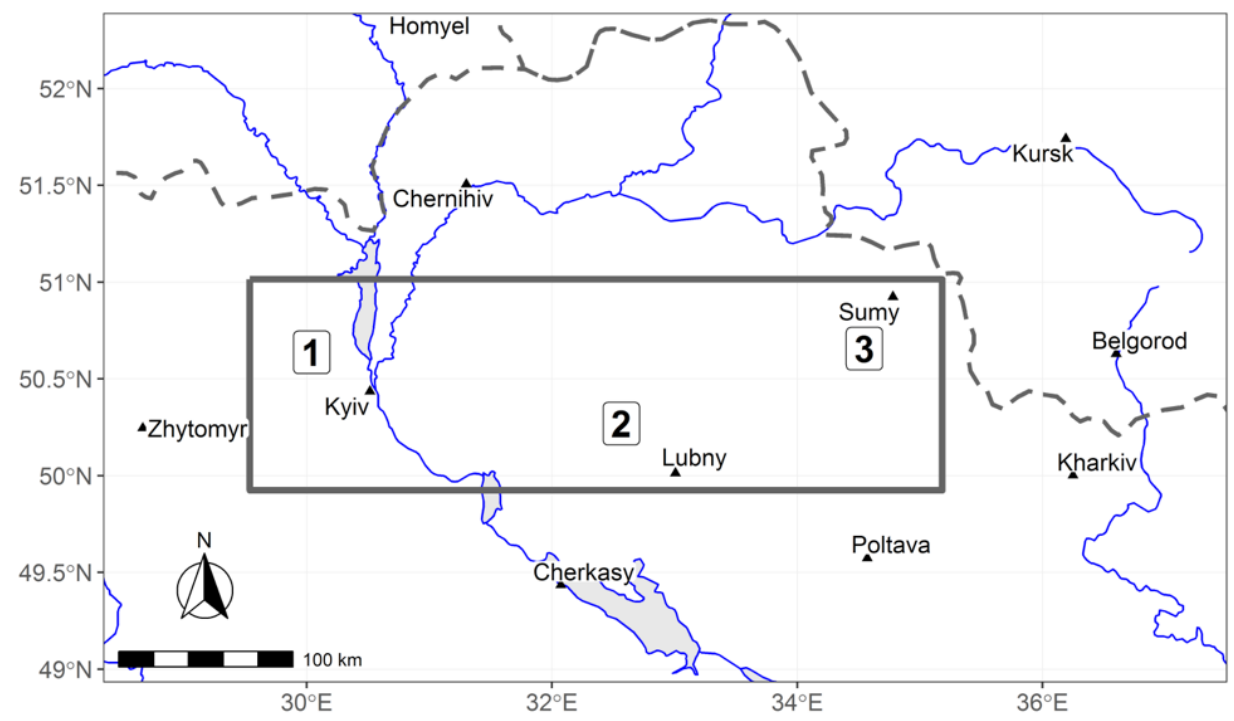

Fig. 1. Study region in central-eastern Ukraine (rectangle). Associations of dry-mesic oak forests: 1 - ass. Digitali grandiflorae-Quercetum roboris, 2 - ass. Carici praecocis-Quercetum roboris, 3 - ass. Galio tinctoriae-Quercetum roboris

The climate of the territory is subcontinental. According to the Köppen-Geiger climate classification it is of $D f b$ type, namely warm-summer humid continental climate (Kottek et al. 2006). In Kyiv's location, the annual average temperature is $7.7^{\circ} \mathrm{C}$; the period of the temperatures above $+10^{\circ} \mathrm{C}$ continues $155-175$ days, the year's total rainfall is $640 \mathrm{~mm}$ (Osadchy et al. 2010). The climatic conditions are not significantly different throughout the region of research: maximal difference in annual temperatures in any direction within the study region does not exceed $1^{\circ} \mathrm{C}$, and the maximal difference in year's rainfalls is below $80 \mathrm{~mm}$.

Relief of the western part of the region, in the Kyiv Polissya, are embodied by sand-moraine terraced complexes with sod-podzolic soils on which pine and pine-oak forests developed. The main river is the Dnieper with its smaller tributaries - Prypiat, Uzh, Teteriv, Zdvyzh and Irpin rivers. The central part of the research area (Poltava region) is located in the northern part of the forest- 
steppe zone within the limits of the Dnieper Lowland. The relief of the territory is plain-wavy rugged by river valleys (the main ones are the left tributaries of the Dnieper - Vorskla, Sula and Psel' rivers).There, the main vegetation types are deciduous forests, meadow-steppes, meadows (floodplain meadows, neutral hay meadows, swampy meadows) and wetlands in lowlands. The eastern part of the region is located on the south-western spurs of the Middle Russian Upland. The Psel' and Vorskla rivers shape landscape of this territory. On watersheds, low-humus deep chernozem is a main type of soils formed from the loamy loess bedrock. Steep slopes of river valleys are covered with deciduous forests. On the river terraces, the prevailing type of soils is sod-podzolic on which pine and pine-oak forests were formed.

\section{Data collection and analyses}

The phytosociological dataset of 123 relevés sampled by the authors was used for vegetation classification. Plots size equalled $400 \mathrm{~m}^{2}$. Species abundances were recorded using the six-point Braun-Blanquet cover-abundance scale. Taxonomic concept in the article follows The Plant List (http://www.theplantlist. org, ver. 1.1). The names and authorship of the syntaxa are in accordance with the EuroVegChecklist (Mucina et al. 2016).

The method of vegetation classification of DRSA, Distance-Ranked Sorting Algorithm, (Goncharenko 2015a, b) was applied for obtaining primary phytocoenotic clusters. Differential species were determined by the concept of fidelity (Bruelheide 2000; Chytrý et al. 2002). The species-to-cluster fidelities were calculated by the Ochiai index (De Cáceres et al. 2008; Cáceres \& Legendre 2009).

The DCA (Hill \& Gauch 1980) was used for ordination because of high heterogeneity of the phytocoenotic data. Calculations were performed using $\mathrm{R}$ software (https://cran.r-project.org) with the decorana function from vegan package (Oksanen et al. 2018). In order to identify gradients and explain them by environmental variables, we applied the ecological indication (phytoindication) method with the use of Didukh's ecological scales for Ukrainian flora (Didukh 2011). Phytoindicational variables were supplementary (passive) so they did not affect the DCA results.

In addition to phytoindicational variables, the phytosociological analysis was also applied. It is an approach of measuring and comparing amounts (fractions) of the species diagnostic of different classes of vegetation in the species composition of the syntaxa. We followed the species-to-class classification adopted in Mucina et al. (2016). Ratios of species from different classes constitute the phytosociological spectrum (Goncharenko et al. 2013) and yield the additional phytosociological variables, which were used together with phytoindicational ones to explain the axes of ordination.

\section{Results and Discussion}

Syntaxonomic scheme of dry-mesic oak forests of the region of research includes 1 class, 1 order, 3 associations, 2 subassociations and 1 variant. 


\section{Syntaxonomic scheme of the studied vegetation}

Quercetea pubescentis Doing-Kraft ex Scamoni et Passarge 1959 Quercetalia pubescenti-petraeae Klika 1933

Alliance: ???

1. Digitali grandiflorae-Quercetum roboris ass. nova hoc loco Carici praecocis-Quercetum roboris ass. nova hoc loco

2. Carici praecocis-Quercetum roboris typicum

3. Carici praecocis-Quercetum roboris var. Agrostis vinealis Galio tinctoriae-Quercetum roboris Goncharenko 2003

4. Galio tinctoriae-Quercetum roboris violetosum mirabilis subass. nova hoc loco

5. Galio tinctoriae-Quercetum roboris dianthetosum fisheri subass. nova hoc loco

The synoptic table is provided in Table 1 and the relevé table is placed in the electronic supplement (Table S1).

In the syntaxonomic scheme the syntaxa were not assigned at the alliance level. As mentioned, in Ukraine and Russia dry-mesic oak forests are most often classified into two alliances: Aceri tatarici-Quercion and Quercion petraeae (incl. Potentillo albae-Quercion petraeae Jakucs in Zólyomi 1967). In our opinion, apparently the distribution areas of these alliances do not reach Ukraine and Western Russia. The Quercion petraeae is Central European alliance and the Aceri tatarici-Quercion is the Pannonian-Pontic alliance (Mucina et al. 2016). The study region, that is in the Sarmatian floristic province (Meusel et al. 1965), lies outside of both - the more western Quercion petraeae and the more southern - Aceri tatarici-Quercion. Some historical notes may clarify the issue. H. Zólyomi introduced the Aceri tatarici-Quercion alliance (Zólyomi 1957), and, obviously, at that time the author simply did not have complete information from Ukraine since he relied on the data from F. Greenj (Greenj 1940) and M. Kotov (Kotov \& Karnaukh 1940). We support the understanding of the Aceri tatarici-Quercion alliance in its narrow sense as oak forests mainly in the Pannonian region of Hungary. The Potentillo albae-Quercion petraeae alliance is based on the association from Germany (Libbert 1933). The differences between the East and Central European dry-mesic oak forests, with particular attention to the alliances Quercion petraeae / Potentillo albae-Quercion petraeae, have been shown and discussed (Semenishchenkov 2012; Bulokhov \& Semenishchenkov 2013). We refrained from placing the syntaxa from the north-eastern part of Ukraine in the mentioned alliances until more comparative material is obtained from these territories.

\section{Ordination analysis}

Syntaxa are distinctive in the ordination space with syntaxa 3 and 4 stretched along the first ordination axis and syntaxa 1 and 2 - along the second axis (Fig. 2). First axis captures $6.8 \%$ of total variation, and first two axes together $-12.8 \%$ of total variation. 
Tab. 1. Synoptic table with species percentage constancies. Values above $\mathbf{4 0} \%$ marked in bold. Only species with at least $\mathbf{2 0} \%$ constancy in any syntaxon are shown. For full species composition see Table S1

\begin{tabular}{|c|c|c|c|c|c|}
\hline ID syntaxon & 1 & 2 & 3 & 4 & 5 \\
\hline Number of relevés & 15 & 26 & 11 & 12 & 8 \\
\hline \multicolumn{6}{|c|}{ D.s. Digitali grandiflorae-Quercetum roboris ass. nova } \\
\hline Teucrium chamaedrys & 87 & & & & \\
\hline Galium boreale & 80 & & & 8 & 12 \\
\hline Serratula tinctoria & 60 & & & & \\
\hline Digitalis grandiflora & 67 & 8 & 9 & & \\
\hline
\end{tabular}

D.s. Carici praecocis-Quercetum roboris typicum

\begin{tabular}{lllll} 
Fragaria viridis & 77 & 9 & 8 & \\
Viola suavis & 42 & & & \\
Carex michelii & 73 & 8 & 25 \\
\hline
\end{tabular}

D.s. Carici praecocis-Quercetum roboris var. Agrostis vinealis

$\begin{array}{lcc}\text { Agrostis vinealis } & 7 & 100 \\ \text { Crepis tectorum } & 55 \\ \text { Lactuca quercina } & & 36\end{array}$

D.s. Carici praecocis-Quercetum roboris ass. nova

Allium oleraceum

Carex montana

$\begin{array}{llll}27 & 46 & 55 & 17\end{array}$

Carex praecox

$\begin{array}{llll}7 & 65 & 27 & 25\end{array}$

Crataegus rhipidophylla

$\begin{array}{lll}7 & 85 & 36\end{array}$

Agrimonia eupatoria

$\begin{array}{lll}27 & 58 & 18\end{array}$

$20 \quad 50 \quad 9$

Acer campestre

$46 \quad 18$

D.s. Galio tinctoriae-Quercetum roboris violetosum mirabilis subass. nova

Viola mirabilis

Vicia sepium

8

Lathyrus vernus

8

D.s. Galio tinctoriae-Quercetum roboris dianthetosum fisheri subass. nova

Dianthus fischeri

Pilosella officinarum

7

Veronica spicata

100

D.s. cl. Quercetea pubescentis

Acer tataricum

Melampyrum nemorosum

Chamaecytisus ruthenicus

13

8

Anthericum ramosum

Campanula persicifolia

Pyrus pyraster

13

38

Hylotelephium maximum

Clematis recta

$\begin{array}{lllll}47 & 81 & 36 & 75 & 25\end{array}$

$\begin{array}{lllll}27 & 77 & 9 & 75 & 75\end{array}$

$\begin{array}{lllll}60 & 46 & 45 & 8 & 75\end{array}$

Asperula tinctoria

$\begin{array}{lllll}87 & 46 & 55 & 8 & 38\end{array}$

Potentilla alba

$\begin{array}{lllll}27 & 35 & 45 & 33 & 25\end{array}$

$\begin{array}{llll}67 & 50 & 27 & 8\end{array}$

$\begin{array}{lllll}67 & 35 & 9 & 8 & 25\end{array}$

$\begin{array}{lllll}33 & 27 & 36 & 25 & 12\end{array}$

Tanacetum corymbosum

$\begin{array}{lllll}40 & 35 & 9 & 25 & 25\end{array}$

$47 \quad 31 \quad 25$

$\begin{array}{llll}27 & 38 & 9 & 25\end{array}$ 
Tab. 1. - cont.

\begin{tabular}{|c|c|c|c|c|c|}
\hline ID syntaxon & 1 & 2 & 3 & 4 & 5 \\
\hline Number of relevés & 15 & 26 & 11 & 12 & 8 \\
\hline Viola hirta & 13 & 38 & 9 & 17 & 12 \\
\hline Campanula bononiensis & 47 & 23 & 18 & & \\
\hline Lathyrus niger & 20 & 12 & 18 & & \\
\hline Iris arenaria & & 19 & 27 & & \\
\hline Lathyrus sylvestris & & 31 & 9 & & \\
\hline \multicolumn{6}{|l|}{ D.s. cl. Trifolio-Geranietea } \\
\hline Betonica officinalis & 73 & 65 & 55 & 67 & 62 \\
\hline Veronica chamaedrys & 73 & 77 & & 83 & 62 \\
\hline Polygonatum odoratum & 67 & 62 & & 92 & 88 \\
\hline Peucedanum oreoselinum & 67 & 65 & 27 & 33 & 88 \\
\hline Clinopodium vulgare & 60 & 54 & 36 & 67 & 25 \\
\hline Silene nutans & 60 & 58 & & 8 & 88 \\
\hline Securigera varia & 60 & 65 & 27 & 17 & 50 \\
\hline Genista tinctoria & 67 & 23 & 36 & & 75 \\
\hline Trifolium alpestre & 67 & 65 & 27 & 25 & 25 \\
\hline Geranium sanguineum & 60 & 54 & 27 & 42 & 12 \\
\hline Hypericum perforatum & 73 & 50 & 9 & 33 & 25 \\
\hline Fragaria vesca & 80 & & 45 & 17 & 38 \\
\hline Vincetoxicum hirundinaria & 53 & 62 & 18 & 8 & 12 \\
\hline Solidago virgaurea & 47 & 19 & 18 & 17 & 50 \\
\hline Astragalus glycyphyllos & 47 & 35 & 18 & 8 & 12 \\
\hline Origanum vulgare & 53 & 38 & & & 25 \\
\hline Ajuga genevensis & 13 & 46 & 18 & 8 & 12 \\
\hline Filipendula vulgaris & 7 & 46 & 9 & 25 & \\
\hline Knautia arvensis & 20 & 15 & 27 & 8 & 12 \\
\hline Trifolium medium & 13 & 35 & & & \\
\hline Centaurea phrygia & 7 & 23 & 9 & & \\
\hline Campanula rapunculoides & & 23 & 9 & & \\
\hline \multicolumn{6}{|l|}{ D.s. cl. Carpino-Fagetea } \\
\hline Quercus robur & 100 & 100 & 100 & 100 & 75 \\
\hline Melica nutans & 67 & 42 & & 92 & 75 \\
\hline Poa nemoralis & 53 & 65 & & 67 & 75 \\
\hline Stellaria holostea & & 77 & 27 & 83 & 12 \\
\hline Euonymus verrucosus & 47 & 42 & 45 & 42 & 12 \\
\hline Corylus avellana & 13 & 35 & 36 & 50 & 25 \\
\hline Asarum europaeum & 7 & 12 & 27 & 75 & 25 \\
\hline Carex digitata & 60 & & & 25 & 38 \\
\hline Tilia cordata & 13 & 38 & 9 & 67 & \\
\hline Festuca gigantea & 60 & 15 & & 33 & \\
\hline Milium effusum & & 19 & & 58 & 25 \\
\hline Euonymus europaeus & 13 & 46 & 27 & 8 & \\
\hline Brachypodium sylvaticum & 27 & 8 & 9 & 33 & \\
\hline Ranunculus auricomus & & 23 & & 33 & \\
\hline
\end{tabular}


Tab. 1. - cont.

\begin{tabular}{|c|c|c|c|c|c|}
\hline ID syntaxon & 1 & 2 & 3 & 4 & 5 \\
\hline Number of relevés & 15 & 26 & 11 & 12 & 8 \\
\hline Acer platanoides & & 42 & 9 & & \\
\hline Carex pilosa & & 15 & & 25 & \\
\hline Carpinus betulus & 20 & & & & \\
\hline \multicolumn{6}{|c|}{ D.s. cl. Quercetea robori-petraeae } \\
\hline Convallaria majalis & 80 & 27 & 73 & 83 & 62 \\
\hline Pinus sylvestris & 53 & 54 & 82 & 25 & 62 \\
\hline Pteridium aquilinum & 80 & 23 & 100 & 50 & 12 \\
\hline Frangula alnus & 33 & 19 & 73 & 33 & 75 \\
\hline Sorbus aucuparia & 53 & 12 & 18 & 33 & 50 \\
\hline Betula pendula & 20 & 31 & 45 & 17 & 12 \\
\hline Dryopteris carthusiana & & 4 & 82 & 17 & 12 \\
\hline Rubus saxatilis & 7 & & & 100 & \\
\hline Hieracium umbellatum & 47 & & & 17 & 38 \\
\hline Rubus idaeus & 7 & 31 & 55 & & \\
\hline Veronica officinalis & 53 & 12 & 9 & & \\
\hline Calamagrostis arundinacea & 47 & & & 17 & \\
\hline Melampyrum pratense & 40 & & & 17 & \\
\hline Maianthemum bifolium & & & 27 & 17 & 12 \\
\hline Molinia caerulea & & 4 & 27 & 8 & \\
\hline Prunus serotina & 33 & & & & \\
\hline \multicolumn{6}{|l|}{ D.s. cl. Festuco-Brometea } \\
\hline Poa angustifolia & 60 & 92 & 73 & 8 & 38 \\
\hline Galium verum & 20 & 73 & 27 & & 62 \\
\hline Euphorbia cyparissias & 73 & 27 & 45 & & \\
\hline Carex caryophyllea & & 27 & 18 & & 25 \\
\hline Bromus inermis & 40 & & & 8 & \\
\hline Verbascum lychnitis & & 54 & & & \\
\hline Anthyllis macrocephala & & & 36 & & \\
\hline Thymus pannonicus & & & & & 25 \\
\hline Salvia nemorosa & & 23 & & & \\
\hline \multicolumn{6}{|c|}{ D.s. cl. Molinio-Arrhenatheretea } \\
\hline Dactylis glomerata & 53 & 81 & 55 & 75 & 25 \\
\hline Calamagrostis epigejos & 13 & 50 & 82 & & 62 \\
\hline Elymus repens & 47 & 12 & 27 & 8 & 100 \\
\hline Agrostis capillaris & 60 & 35 & 9 & & 88 \\
\hline Galium mollugo & 73 & & & 58 & 38 \\
\hline Achillea millefolium & 73 & 31 & 18 & & 50 \\
\hline Ranunculus polyanthemos & 40 & 92 & & 17 & \\
\hline Viscaria vulgaris & 13 & 42 & 27 & 8 & 12 \\
\hline Stellaria graminea & & 38 & & & 50 \\
\hline Festuca rubra & 20 & & & & 25 \\
\hline Prunella vulgaris & 27 & & & & \\
\hline Leucanthemum vulgare & & 23 & & & \\
\hline
\end{tabular}


Tab. 1. - cont.

\begin{tabular}{|c|c|c|c|c|c|}
\hline ID syntaxon & 1 & 2 & 3 & 4 & 5 \\
\hline Number of relevés & 15 & 26 & 11 & 12 & 8 \\
\hline \multicolumn{6}{|c|}{ D.s. cl. Epilobietea angustifolii } \\
\hline Geum urbanum & 33 & 54 & 36 & 42 & 12 \\
\hline Glechoma hederacea & 20 & 50 & 45 & 33 & 25 \\
\hline Scrophularia nodosa & 33 & 35 & 18 & 25 & 12 \\
\hline Geranium robertianum & 20 & & 64 & 8 & 12 \\
\hline Chelidonium majus & 13 & 4 & 45 & 17 & 12 \\
\hline Lactuca muralis & 13 & 19 & 45 & & \\
\hline Torilis japonica & 40 & & & 25 & \\
\hline Impatiens parviflora & 33 & & 18 & 8 & \\
\hline Urtica dioica & & 4 & & 25 & \\
\hline Fallopia dumetorum & 13 & & 27 & & \\
\hline Galeopsis bifida & & & & 8 & 25 \\
\hline Galeopsis pubescens & & & 27 & & \\
\hline
\end{tabular}

\section{D.s. cl. Artemisietea vulgaris}

Linaria vulgaris

$\begin{array}{lll}20 & 12 & 9\end{array}$

Rumex thyrsiflorus

D.s. cl. Crataego-Prunetea

Rosa sp.

$\begin{array}{lll}27 & 27 & 9\end{array}$

Crataegus ucrainica

$19 \quad 18$

Prunus spinosa

23

D.s. cl. Alno-Populetea albae

Prunus padus

20

25

Humulus lupulus

Populus tremula

$12 \quad 45$

Ulmus laevis

$\begin{array}{lll}20 & 8 & 9\end{array}$

Sambucus nigra

$7 \quad 36$

D.s. cl. Nardetea strictae

Campanula rotundifolia

60

$8 \quad 36$

Carex pallescens

33

$23 \quad 18$

62

Rumex acetosella

Festuca ovina

20

Other species

Epipactis helleborine

27

Hypericum hirsutum

\begin{tabular}{|c|c|c|}
\hline & 27 & \\
\hline \multirow[t]{3}{*}{31} & 36 & \\
\hline & 27 & \\
\hline & 25 & \\
\hline \multirow[t]{2}{*}{7} & 33 & \\
\hline & 25 & \\
\hline \multirow[t]{2}{*}{7} & 25 & 12 \\
\hline & & 25 \\
\hline 7 & & 25 \\
\hline
\end{tabular}




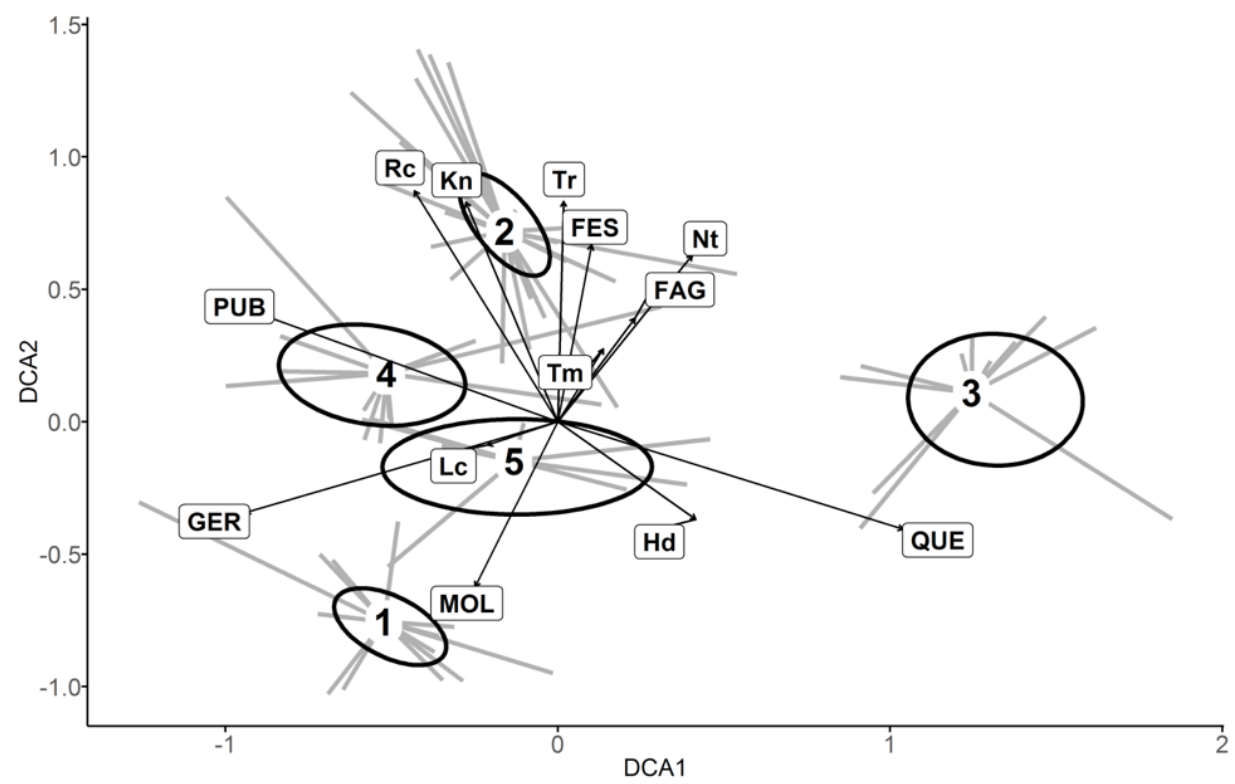

Fig. 2. DCA ordination plot. Numbers indicate syntaxa (see syntaxonomic scheme). Vegan's standard errors ellipses were drawn at 0.95 confidence level. Phytoindicational variables: $\mathbf{H d}-$ moisture, Lc - light value, $\mathrm{Rc}$ - soil reaction $\mathrm{Nt}$ - nitrogen, $\mathrm{Tm}$ - temperature $\mathrm{Kn}$ - continentality, $\mathrm{Tr}$ - salt regime. Classes of vegetation: FAG - Carpino-Fagetea, FES - Festuco-Brometea, GER - Trifolio-Geranietea, MOL - Molinio-Arrhenatheretea, PUB - Quercetea pubescentis, QUE Quercetea robori-petraeae

In Table 2 all variables that are passively projected onto the ordination space were sorted by determination coefficient $r^{2}$ of multiple regression tested by the envfit function, which is a measure of the relations between variables and ordination scores.

Two phytosociological variables QUE (Quercetea robori-petraeae) and GER (Trifolio-Geranietea) have the greatest contribution to the floristic differentiation of the studied vegetation, being both mostly correlated with the first axis of ordination (Table 2). Among the environmental factors, $R c$ and $K n$ were the largest contributors. The length of the vectors in Fig. 2 and the $r^{2}$ values in the Table 2 are not related to the extent to which the factor is critical (important) for the growth of forests of the studied type, but reflects to what extent and in which syntaxa it plays a differentiating role. For example, the vector $L c$ is the shortest because all the studied forest stands are light with closeness of tree canopy ranges $0.5-0.6$. At the same time, soil reaction differs much with the long $R c$ vector that is directed to syntaxon 2 (neutral or basiphilous soils). As can be seen from Fig. 2, types of other classes of vegetation, including forest (Quercetea robori-petraeae, Carpino-Fagetea) and herbaceous (Trifolio-Geranietea, FestucoBrometea, Molinio-Arrhenatheretea) types take a significant part in the species composition of syntaxa. This is important given the controversial syntaxonomy of 
Tab. 2. Summarized outputs of the multiple regression analysis showing relations of 13 supplementary (passive) variables to the first two ordination axes

\begin{tabular}{ll|cccc}
\hline Notations & Supplementary variables & DCA1 & DCA2 & $\mathrm{r}^{2}$ & $\mathrm{r}^{2}$.ranked \\
\hline QUE & Quercetea robori-petraeae & 0.693 & -0.271 & 0.553 & 1 \\
GER & Trifolio-Geranietea & -0.626 & -0.228 & 0.444 & 2 \\
Rc & soil reaction & -0.288 & 0.581 & 0.421 & 3 \\
PUB & Quercetea pubescentis & -0.580 & 0.264 & 0.406 & 4 \\
Kn & continentality value & -0.184 & 0.553 & 0.339 & 5 \\
Tr & total salt regime & 0.012 & 0.555 & 0.308 & 6 \\
Nt & nitrogen value & 0.269 & 0.419 & 0.248 & 7 \\
FES & Festuco-Brometea & 0.068 & 0.445 & 0.203 & 8 \\
MOL & Molinio-Arrhenatheretea & -0.166 & -0.415 & 0.200 & 9 \\
Hd & moisture value & 0.277 & -0.246 & 0.137 & 10 \\
FAG & Carpino-Fagetea & 0.155 & 0.261 & 0.092 & 11 \\
Tm & temperature value & 0.092 & 0.183 & 0.042 & 12 \\
Lc & lightness value & -0.141 & -0.059 & 0.023 & 13 \\
\hline Eigenvalues of axes & 0.44 & 0.39 & & \\
Variation explained, \% & 6.80 & 6.00 & 2.43 & \\
Axis lengths & & 3.11 & & \\
\hline
\end{tabular}

dry-mesic forests in the northeastern regions. Species composition of the studied vegetation is ecotonic and there are gradual series from typical communities to the communities of other mentioned classes since they are usually located near forest edges and in light (open-canopy) stands and may be bordered by different types of vegetation - meadow-steppes, broad-leaved forests, xeric scrub vegetation and pine forests.

\section{General description}

Habitat. In the studied region, dry-mesic oak forests occupy two different habitat types. First type («terrace» forests) is connected with sandy soils and the gentle relief of river terraces, where oak forests are usually concentrated on the second (boreal) terrace and are surrounded by xeric pine forests, which prevail in areas. Here, unlike pine forests, fragments of pure oak stands, or at least with a pronounced predominance of oak over pine in the tree layer, usually occupy various lowering of the boreal terraces, where heavier water-resistant clay strata are necessarily included in sandy sediments. This also affects soil fertility and humidity, which is higher than that of the surrounding pine forests. Terrace oak forests are more northern, located mainly in the southern part of the forest zone and gradually become rarer in the south, in the forest-steppe zone. The second type of oak forests ("ravine" forests) confined to elevated and eroded areas - on the steep slopes of river valleys, ravines on watersheds (called 
"bayracks" in the forest-steppe landscape) and sometimes on the high (third fourth) river terraces, where the soils are heavier and more similar to those on the watersheds. Soils are fertile on loam-loess bedrocks, usually gray forest soils, and podzolized chernozems as well in the south.

Tree layer. Dry-mesic oak forests have a sparse tree layer and are mainly formed by the late form of oak (Quercus robur var. tardiflora). Unlike the CentralSouthern Europe, where many Quercus species grow (Quercus petraea, Q. pubescens, $Q$. cerris, $Q$. frainetto), only Quercus robur goes so far to the east. The participation of other tree species does not exceed $30 \%$, varies from region to region. Boreal tree species, like Pinus sylvestris and Betula pendula, often come from the surrounding pine forests which prevail on boreal terraces of rivers in the region. In the western part of the study region, Carpinus betulus still occurs and disappears gradually eastward. In the eastern locales of the region, Tilia cordata and Acer platanoides become main oak companions. To the south, Fraxinus excelsior and Pyrus pyraster also become more frequent.

Shrub layer. The shrub layer is species-rich and its composition depends. In the terrace oak forests there are many species that are common with the pine forests (Chamaecytisus ruthenicus, Genista tinctoria, Frangula alnus, Sorbus aucuparia). The ravine oak forests are more characterized by the species of the CrataegoPrunetea class (Prunus spinosa, Acer tataricum, Crataegus rhipidophylla etc.).

Herbaceous layer. Like the shrub layer, herbaceous layer is species-rich with the average number of species per relevé varies from 30 to 60 , increasing in the light stands. Total coverage of the layer ranges from 70 to $90 \%$. There is a mixture of grasses (Poa angustifolia, Calamagrostis epigeios, Festuca rubra, Agrostis capillaris, A. giganthea) with light-demanding forest-edge species (Geranium sanguineum, Betonica officinalis, Trifolium alpestre, Securigera varia). On sandy soils oak forests have more common species with the surrounding xeric pine forests (Solidago virgaurea, Hypericum perforatum, Peucedanum oreoselinum, Calamagrostis arundinacea). The ravine type of oak forests is bordering broadleaved forests and meadow-steppe communities, and therefore includes more floristic elements of steppe vegetation in light stands and of fagetalic forests in shady conditions.

Correspondence to the units of dominant classification. According to the former dominant classification, which was the main classification approach for a long time in the USSR, the dry-mesic oak forests were attributed to two different groups: the terrace oak forests were mainly reported as Querceta roboris convallariosa, Querceta roboris pteridiosa from many locations throughout Ukraine, except for the south (steppe part) of the country, and the ravine oak forests type were mentioned as Querceta roboris violosa hirtae, Querceta roboris caricosa montanae, Querceta roboris lithospermosa, Querceta roboris melicosa pictae (Bradis 1971). The last two are not distributed within the region of research.

Conservation value. In dry-mesic oak forests many threatened species occur: Digitalis grandiflora, Potentilla alba, Epipactis helleborine, Dianthus fisheri, Lilium martagon etc. High naturalness, floristic richness, and limited distribution, all they evidence for the needs of protection of communities. 


\section{Description of syntaxa}

Quantitative data calculated by the header data of relevés (average number of species, coverage of each layer) and derived from species composition of synoptic columns (homotoneity coefficient, Moravec 1973) were aggregated for each syntaxon (Table 3). Synantropization and adventization indices (SudnikWójcikowska 1991) and the ratios of species of Raunkier's life forms were added to characteristics. Common features of all studied syntaxa are: high floristic richness; similar layer structure; low synantropization indices (ISyn, IAd) and quantities of terophytes (T \%); high fraction of nanophanerophytes to phanerophytes ( $\mathrm{nPh} / \mathrm{Ph})$.

Tab. 3. Descriptive statistics and the structure of syntaxa

\begin{tabular}{|c|c|c|c|c|c|c|c|c|c|c|c|c|c|c|c|c|}
\hline \multirow{2}{*}{$\begin{array}{l}\text { ID } \\
\text { synt. }\end{array}$} & \multirow{2}{*}{$\mathbf{N}$} & \multicolumn{3}{|c|}{ floristic richness } & \multicolumn{2}{|c|}{$\begin{array}{l}\text { Ht, const. } \\
\text { species,\% }\end{array}$} & \multicolumn{3}{|c|}{$M_{c^{\prime}}$ coverage of layers } & \multirow{2}{*}{ ISyn } & \multirow{2}{*}{ IAd } & \multicolumn{5}{|c|}{$\begin{array}{c}\text { Raunkier's life } \\
\text { forms, \% }\end{array}$} \\
\hline & & $\mathbf{S}$ & $\mathbf{R}$ & $\Delta \mathbf{R}$ & $K_{20}$ & $K_{40}$ & trees & shrubs & herbs & & & $\mathrm{Ph}$ & $\mathrm{nPh}$ & G & $\mathbf{H}$ & $\mathbf{T}$ \\
\hline 1 & 15 & 164 & 47 & $30-60$ & 51 & 32 & 55 & 11 & 71 & 18 & 1 & 11 & 7 & 13 & 63 & 6 \\
\hline 2 & 11 & 128 & 35 & $38-60$ & 45 & 20 & 77 & 12 & 89 & 29 & 2 & 12 & 10 & 16 & 56 & 6 \\
\hline 3 & 26 & 146 & 44 & $27-40$ & 53 & 30 & 62 & 7 & 70 & 14 & 0 & 9 & 7 & 13 & 70 & 1 \\
\hline 4 & 12 & 116 & 33 & $26-37$ & 46 & 22 & 66 & 6 & 79 & 13 & 0 & 11 & 8 & 15 & 63 & 3 \\
\hline 5 & 8 & 84 & 31 & $35-56$ & 55 & 37 & 57 & 11 & 58 & 13 & 0 & 9 & 11 & 12 & 63 & 5 \\
\hline
\end{tabular}

Legend: ID - syntaxon number, the same as in the syntaxonomic scheme, $N$-number of relevés in the cluster; $S$ - total number of species in joint species list of syntaxon; $R$ - average number of species per relevé; $\Delta \boldsymbol{R}-\min$-max ranges of number of species in the relevés of the cluster; $H t$-the homotoneity coefficient, the number of species with constancies higher than $20 \%(40 \%)$ divided by the average number of species in the relevés; $M_{c}$ - average of the releve header data on coverage of tree, shrub, herb layers; ISyn - the synantropization index; Raunkier's life forms ( $P h$ - phanerophytes, $n P h$ - nanophanerophytes, $\mathbf{G}$ - geophytes, $\boldsymbol{H}$ - hemicryptophytes, $T$ - therophytes)

Synanthropic indices are low and most synanthropic species are apophytes which do not transform natural communities. For alien species, the adventization index is negligible (0-2\%). There is a decrease in floristic richness from syntaxon 1 to 5. For example, communities in Polissya are richer than in Forest-Steppe (47 and 31 species per relevé in average). In the biomorph structure, hemicryptophytes are the most numerous, both in quantities $(\mathrm{H} \%, 56-70 \%)$ and in coverage in the herbaceous layer which is mainly formed by them $\left(\mathrm{M}_{\mathrm{c}^{\prime}} 58-89 \%\right)$. The closeness of the trees varies from 55 to $77 \%$. In most cases these forests are light and warm which promotes the richness of herbs and shrubs. In contrast to high alphadiversity, the beta-diversity is quite low. The average similarity of communities can be judged by the $\mathrm{Ht}$ index. Species with constancies above $40 \%$ make up to $37 \%$ and above $20 \%$ - up to $55 \%$ of species lists considering the average number of species in relevés. 


\section{Association Digitali grandiflorae-Quercetum roboris ass. nova}

Holotypus: relevé 76 (Table S1). Author of the relevé: I. Goncharenko. Date: 27.05.2017. Coordinates: $50.5702^{\circ} \mathrm{N}, 30.3224^{\circ} \mathrm{E}$. Location: Ukraine, Kyiv region, near the village Horenka. Habitat: dry-mesic pine-oak forest on sandy (boreal) terrace of the Irpin' river. Coverage of layers: trees - $80 \%$, shrubs - 15\%, herbs - 75\%; mosses - less than 1\% (not identified). Number of species: 43. Tree layer: Quercus robur 3, Pinus sylvestris 1, Pyrus pyraster +. Shrub layer: Chamaecytisus ruthenicus 2, Genista tinctoria 2, Euonymus verrucosus +, Prunus serotina + , Rosa sp. +. Herbaceous layer: Pteridium aquilinum 3, Anthericum ramosum 2, Betonica officinalis 2, Campanula rotundifolia 2, Carex digitata 2, Clinopodium vulgare 2, Convallaria majalis 2, Euphorbia cyparissias 2, Festuca gigantea 2, Fragaria vesca 2, Galium boreale 2, Peucedanum oreoselinum 2, Poa angustifolia 2, Polygonatum odoratum 2, Potentilla alba 2, Serratula tinctoria 2, Silene nutans 2, Agrostis capillaris 1, Carex muricata 1, Digitalis grandiflora 1, Geranium sanguineum 1, Luzula multiflora 1, Melica nutans 1, Poa nemoralis 1, Teucrium chamaedrys 1 , Veronica chamaedrys $1, V$. officinalis 1 , Vincetoxicum hirundinaria 1, Achillea millefolium +, Calamagrostis arundinacea +, Galium mollugo + , Hypericum perforatum + , Hypochaeris radicata + , Linaria vulgaris + , Viscaria vulgaris + .

Communities develop on boreal terrace of the Irpin' river, but the expected range of association is wider, covering the southern part of the forest zone within Kyiv and other eastern regions in Polissya. Absolute heights range from 143 to $147 \mathrm{~m}$ a.s.l.; mesorelief is hilly; soils are sod-podzolic and slightly acidic. Pure oak stands are confined to lower parts of the terrace and mixed pine-oak stands occur on gentle slopes (5-10 inclination) of dunes of the boreal terrace, mainly of south-facing expositions. In the tree layer, the late oak Quercus robur var. tardiflora is dominated. An admixture of Pinus sylvestris is not exceeding $20 \%$ with both species in the same tree layer. Other tree species (Betula pendula, Populus tremula, Carpinus betulus, Tilia cordata etc.) are less frequent. The total coverage of shrub layer is $5-30 \%$. Unlike the monotypic tree layer, the shrub layer is species-rich (Acer tataricum, Berberis vulgaris, Chamaecytisus ruthenicus, Clematis recta, Euonymus verrucosa, Frangula alnus, Genista tinctoria, Padus serotina, Sorbus aucuparia). Herb layer is composed of grasses and light-demanding and xeromesophytic dicots. Among grasses, several groups are combined: meadow (Dactylis glomerata, Agrostis capillaris, Festuca rubra), meadow-steppe (Poa angustifolia, Bromus inermis) and nemoral grasses (Festuca gigantea, Melica nutans). An interesting fact indicating a connection with thermophilous forests is a high constancy of sub-Mediterranean species Teucrium chamaedrys, which is found here on the northern distribution border. Like Central European forests of similar type, thermophilous species (Serratula tinctoria, Anthericum ramosum, Potentilla alba etc.) are present as well as some East-European (Chamaecytisus ruthenicus, Acer tataricum) and species of wide distribution range, especially in the northern regions (Calamagrostis arundinacea, Galium boreale, Hieracium umbellatum, Melampyrum pratense, Pinus sylvestris, Veronica officinalis). 


\section{Association Carici praecocis-Quercetum roboris ass. nova}

Holotypus: relevé 82 (Table S1). Author of the relevé: O. Kovalenko. Date: 16.06.2013. Coordinates: $50.2687^{\circ} \mathrm{N}, 32.5658^{\circ} \mathrm{E}$. Location: Ukraine, Poltava region, Piryatin district, near the village Kharkivtsi. Habitat: dry-mesic oak forest in the outer part of forest massif bordering open areas covering with psammophytic meadows of Agrostion vinealis alliance. Coverage of layers: trees $-50 \%$, shrubs $-20 \%$, herbs $-60 \%$; mosses $-0 \%$. Number of species: 36 . Tree layer: Quercus robur 5, Ulmus minor 2. Shrub layer: Chamaecytisus ruthenicus 1. Herbaceous layer: Carex michelii 2, Hylotelephium maximum 2, Agrostis capillaris 1, Ajuga genevensis 1, Asarum europaeum 1, Carex ericetorum 1, Euphorbia virgata 1, Fragaria viridis 1, Galium verum 1, Geranium sanguineum 1, Melica nutans 1, Origanum vulgare 1, Peucedanum oreoselinum 1, Poa angustifolia 1 , P. nemoralis 1, Polygonatum odoratum 1, Silene nutans 1, Agrimonia eupatoria +, Anthericum ramosum +, Asperula tinctoria +, Astragalus glycyphyllos + , Campanula persicifolia +, Carex pilosa +, C. praecox + , Clematis recta + , Melampyrum nemorosum + , Milium effusum + , Ranunculus polyanthemos + , Stellaria holostea +, Tanacetum corymbosum +, Veronica chamaedrys + , Viola hirta,+ V. suavis + .

Communities occupy warm and well-drained slopes and uplands. Soils are sod-podzolic from slightly acidic to neutral ( $\mathrm{pH}$ from 6.5 to 7). They have often scattered distribution in drier conditions and are surrounded by xeric pine forests. This vegetation unit represents oak and pine-oak forests with two-layered tree structure. In the first tree layer, Quercus robur is dominated. Pinus sylvestris plays a co-dominating role in the first layer. Second tree layer are formed by various accompanying species like Acer platanoides, Pyrus pyraster and Tilia cordata. The shrub layer is species-rich and composed of Frangula alnus, Crataegus rhipidophylla, Acer tataricum, Prunus spinosa, Euonymus verrucosa, Crataegus ucrainica etc. The herbaceous layer (coverage of 50-80\%) is dominated by Carex praecox, Poa angustifolia, Calamagrostis epigeios.

\section{Association Galio tinctoriae-Quercetum roboris Goncharenko 2003}

The association was described in the northern part of the forest-steppe zone, on the south-western spurs of the Middle Russian Upland in Ukraine (Goncharenko 2003, p. 102). It is the easternmost association within the studied region (Fig. 1). It unites dry-mesic species-rich oak forests in the forest-steppe zone. Using this association as an example, we will demonstrate floristic differences between the two types of previously mentioned oak forests - the terrace type on sandy soils and the ravine type on loamy soils, since this can be especially well traced in the forest-steppe zone-ecotone. Table 4 summarizes the most valuable floristic features of both types (two subassociations in this case).

\section{Subassociation Galio tinctoriae-Quercetum roboris violetosum mirabilis subass. nova (ravine forests)}

Holotypus: relevé 6 (Table S1). Author of the relevé: I. Goncharenko. Date: 09.05.2000. Coordinates: $50.6560^{\circ} \mathrm{N}, 34.5478^{\circ}$ E. Location: Ukraine, Sumy 
Tab. 4. Differentiating table of two edaphic subtypes of dry-mesic oak forests ( 1 - ravine type, Galio-Quercetum subass. violetosum mirabilis, 2 - terrace type, Galio-Quercetum subass. dianthetosum fisheri)

\begin{tabular}{|c|c|c|c|c|c|}
\hline Type of oak forests & 1 & 2 & Type of oak forests & 1 & 2 \\
\hline \multicolumn{3}{|l|}{ Common species } & \multicolumn{3}{|c|}{ Differential species of the type \#2 } \\
\hline Quercus robur & $\mathrm{V}$ & IV & Pinus sylvestris & II & $\mathrm{V}$ \\
\hline Polygonatum odoratum & $\mathrm{v}$ & $\mathrm{V}$ & Dianthus fisheri & . & $\mathrm{V}$ \\
\hline Melica nutans & v & IV & Silene nutans & . & $\mathrm{V}$ \\
\hline Acer tataricum & IV & III & Galium verum & . & $\mathrm{V}$ \\
\hline Poa nemoralis & IV & $\mathrm{V}$ & Genista tinctoria & . & $\mathrm{V}$ \\
\hline Melampyrum nemorosum & IV & IV & Chamaecytisus ruthenicus & . & $\mathrm{V}$ \\
\hline Veronica chamaedrys & $\mathrm{v}$ & III & Agrostis capillaris & . & $\mathrm{V}$ \\
\hline Convallaria majalis & $\mathrm{v}$ & III & Campanula rotundifolia & . & IV \\
\hline Betonica officinalis & IV & III & Calamagrostis epigejos & . & IV \\
\hline \multicolumn{2}{|c|}{ Differential species of the type \#1 } & & Veronica spicata & . & III \\
\hline Viola mirabilis & $\mathrm{v}$ & . & Hieracium umbellatum & . & III \\
\hline Vicia sepium & $\mathrm{v}$ & . & Solidago virgaurea & . & III \\
\hline Asarum europaeum & IV & . & Pilosella officinarum & . & III \\
\hline Tilia cordata & IV & $\cdot$ & & & \\
\hline Lathyrus vernus & IV & . & & & \\
\hline Clinopodium vulgare & IV & . & & & \\
\hline Galium mollugo & III & & & & \\
\hline Corylus avellana & III & . & & & \\
\hline Euonymus verrucosus & III & . & & & \\
\hline
\end{tabular}

region, Lebedyn district, near the village Mezhirich. Habitat: pure oak stands on the upper part of steep $\left(20^{\circ}\right) \mathrm{SW}$-exposited slope of the Psel' river valley. Coverage of layers: trees $-60 \%$, shrubs $-5 \%$, herbs $-80 \%$, mosses are absent. Number of species: 38. Tree layer: Quercus robur 3. Shrub layer: Acer tataricum 2, Clematis recta 1, Chamaecytisus ruthenicus +. Herbaceous layer: Convallaria majalis 2, Poa nemoralis 2, Asperula tinctoria 1, Betonica officinalis 1, Dactylis glomerata 1, Fragaria vesca 1, Geranium sanguineum 1, Lathyrus vernus 1, Melampyrum nemorosum 1, Melica nutans 1, Peucedanum oreoselinum 1, Polygonatum odoratum 1, Rubus saxatilis 1, Stellaria holostea 1, Veronica chamaedrys 1, Vicia sepium 1, Brachypodium sylvaticum +, Campanula persicifolia +, Carex montana + , , Dracocephalum ruyschiana +, Galium mollugo +, Heracleum sibiricum + , Hieracium umbellatum +, Hypericum perforatum +, Iris aphylla +, Milium effusum + , Pteridium aquilinum + , Ranunculus polyanthemos + , Securigera varia + , Silene nutans + , Tanacetum corymbosum +, Vincetoxicum hirundinaria +, Viola mirabilis + , Viscaria vulgaris + .

The subassociation is confined to the gray and dark-gray soils on loess loams and unites forests on slopes of gullies and highest parts of water catchment areas 
of long branched ravines typical of forest-steppe landscape. It is alternating with the fagetalic forests of the alliance Scillo sibericae-Quercion roboris (Onyshchenko 2009 ) in the lower parts of shady slopes. There are common species between them, and the subassociation is differentiated by megatrophic and nemoral species (Table 4). In the previous dominant classification, communities were usually classified as the sociation Querceta roboris caricosum montanae and reported for locations in the Left-Bank Forest-Steppe of Ukraine. According to its characteristics: "oak groves on dark gray forest loams ... which in the past occupied an intermediate position between the maple-lime-oak forests and meadow steppes in the watersheds" (Bradis 1971, p. 288).

\section{Subassociation Galio tinctoriae-Quercetum roboris dianthetosum fisheri subass. nova (terrace forests)}

Holotypus: relevé 1 (Table S1). Author of the relevé: I. Goncharenko. Date: 14.06.2000. Coordinates: $50.7255^{\circ} \mathrm{N}, 34.7041^{\circ}$ E. Location: Ukraine, Sumy region, near the village Patriotivka. Habitat: oak forest on lowered area of second river terrace of Psel' river. Coverage of layers: trees $-60 \%$, shrubs $-10 \%$, herbs - 80\%, mosses are absent. Number of species: 30. Tree layer: Quercus robur 3, Pinus sylvestris +. Shrub layer: Chamaecytisus ruthenicus 2, Acer tataricum 1, Genista tinctoria +, Sorbus aucuparia +. Herbaceous layer: Melampyrum nemorosum 2, Melica nutans 2, Betonica officinalis 1, Convallaria majalis 1, Dactylis glomerata 1, Peucedanum oreoselinum 1, Polygonatum odoratum 1, Stellaria holostea 1, Agrostis capillaris + , Anthoxanthum odoratum + , Asperula tinctoria +, Calamagrostis epigejos +, Campanula rotundifolia + , Carex digitata +, Dianthus fischeri +, Elymus repens +, Galium verum +, Geranium sanguineum +, Origanum vulgare + , Poa angustifolia,+ P. nemoralis + , Silene nutans + , Veronica chamaedrys,+ V. spicata + .

The subassociation occurs on sandy soils, frequently on second (boreal) river terraces of Psel' and Vorskla rivers. Species composition includes many species that are common with the surrounding pine forests (Genista tinctoria, Chamaecytisus ruthenicus, Hieracium umbellatum) and psammophytes (Veronica spicata, Pilosella officinarum). In the previous dominant classification, such communities most often attributed to the sociation Querceta roboris convallarioso-pteridiosa. From its description: "oak forests on podzolic sandy soils ... where the dark-colored humus horizon of $10-20 \mathrm{~cm}$ includes yellow inclusions" (Bradis 1971, p. 290).

\section{Comparative floristic analysis}

In this section, we focus on comparative floristic analysis of the studied syntaxa with similar syntaxa from adjacent territories, thus going beyond the region we have studied. As for criteria for selection of syntaxa for comparison, they are based on floristic, geographic and ecological resemblance to our syntaxa. We were not guided by the similarity of the original syntaxonomic interpretation, since similar syntaxa were included by the authors in various alliances. These data are indicated in the legend of Table 5. 


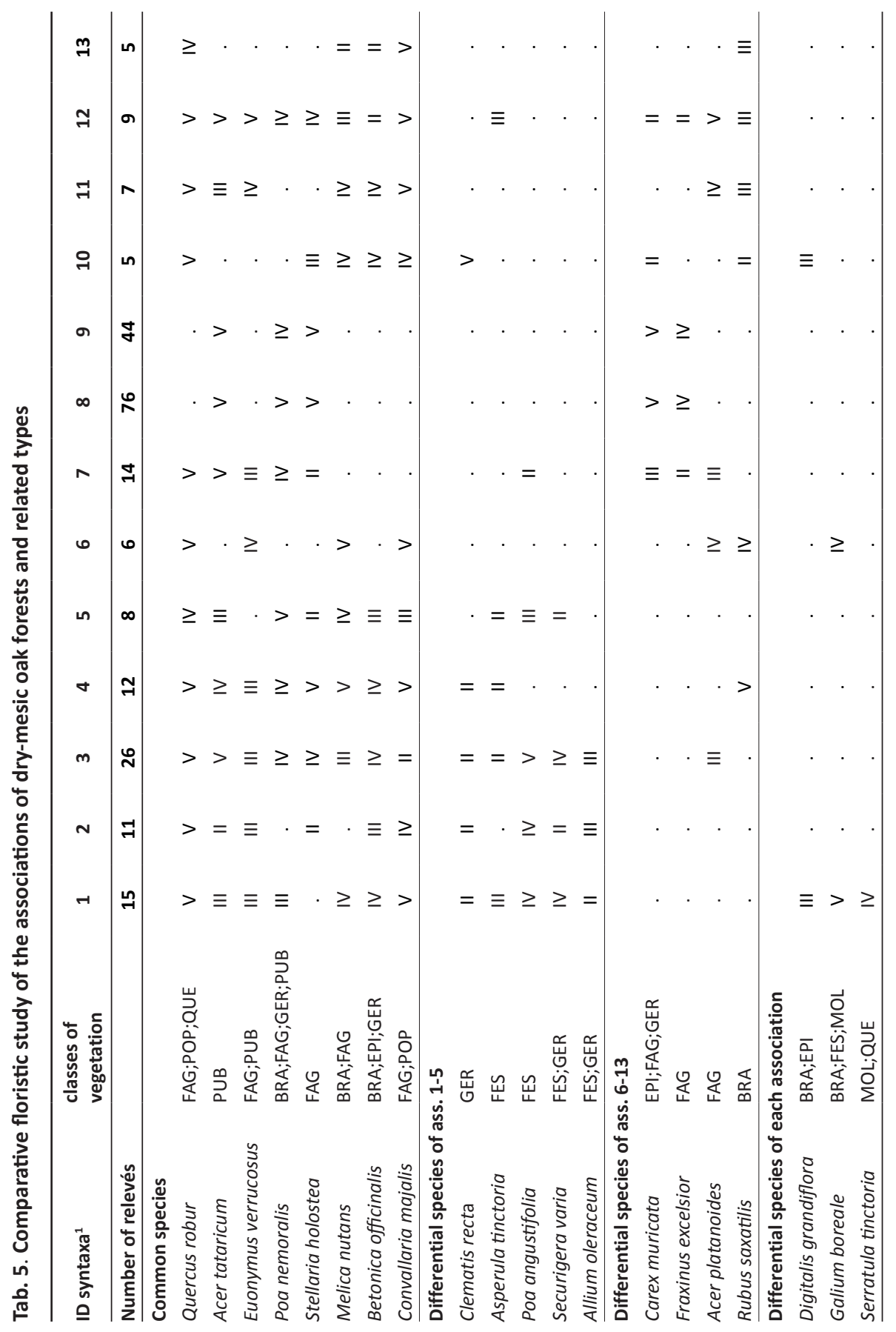




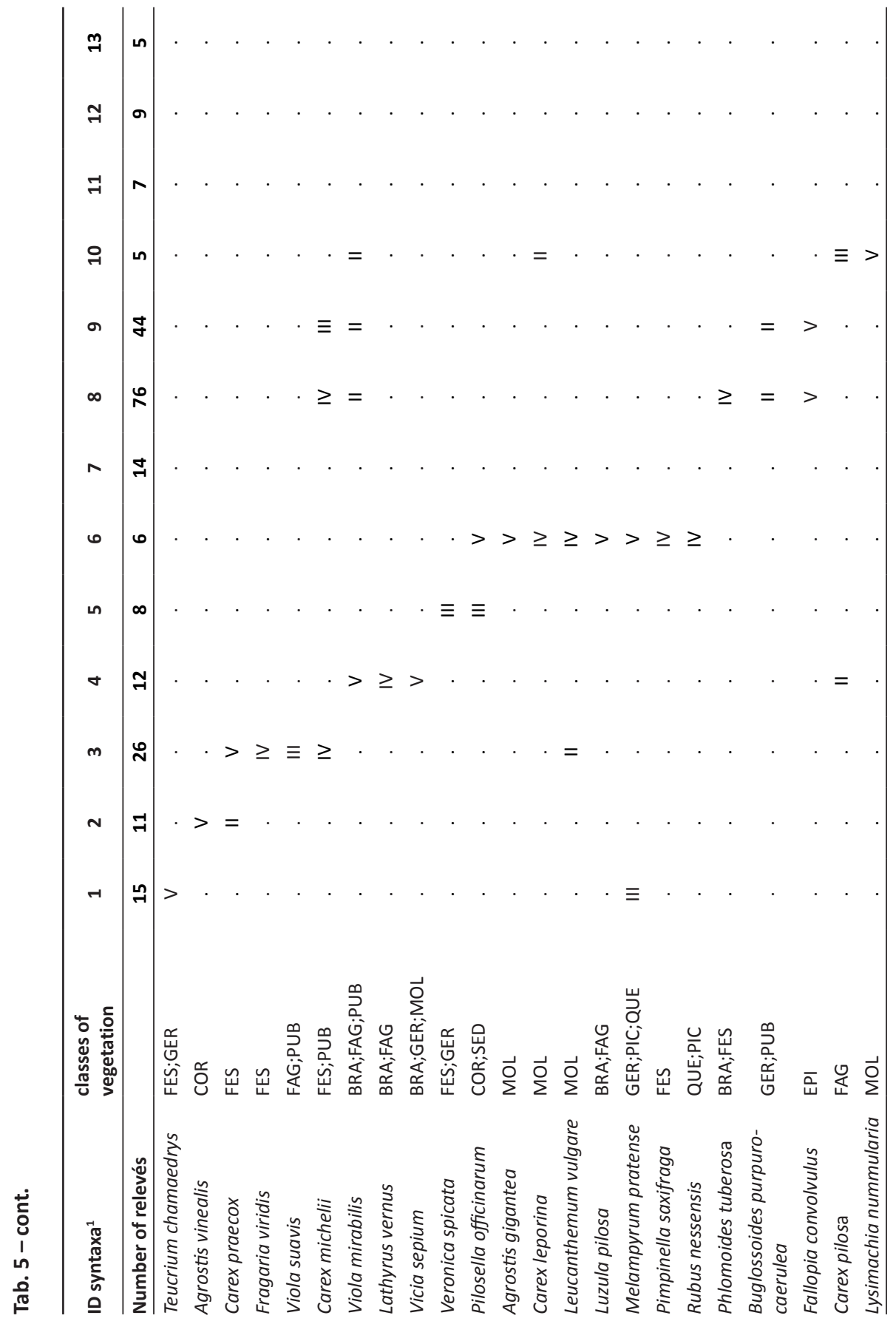




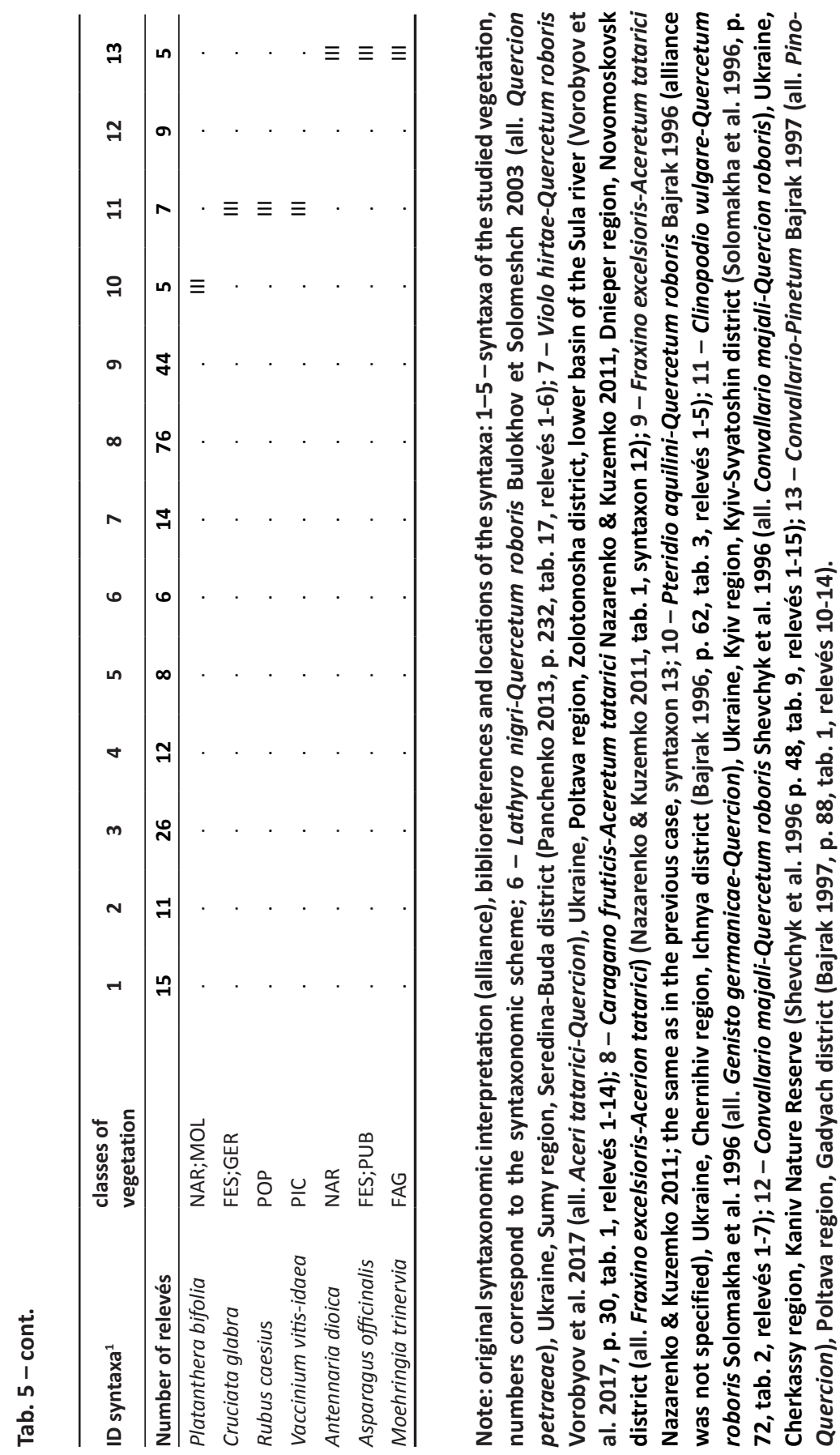


As can be seen from Table 5, syntaxa from the region of research demonstrate floristic differences sufficient to recognize some of them as new ones. Differential species of our syntaxa (1-5) did not change much or disappear after adding associations from a wider region. Two subgroups may be distinguished (1-5 and $6-13)$, but they are not sufficient for assigning to two different vegetation units of higher ranks. Given the number of common species with high constancy, the number of alliances reported by the authors ( 5 alliances, as can be seen from the legend) is likely overestimated. The role of differentiating species in the syntaxa of the southern Ukrainian territories is played by such species as Buglossoides purpurocaerulea, Carex michelii, Fragaria viridis, Phlomoides tuberosa and nemoral species (Lathyrus vernus, Viola mirabilis, Carex pilosa), the proportion of which increases markedly in the ravine forests as well. In contrast, in more northern regions, differentiating species are boreal (Rubus nessensis, Vaccinium vitis-idaea), as well as psamophytic (Pilosella officinarum, Veronica spicata) due to sandy soils, and meadow species (Leucanthemum vulgare, Lysimachia nummularia).

\section{Conclusion}

We presented the results of the floristic-sociological classification of drymesic oak forests, although the coenotic diversity of forests of this type is probably not limited to three established associations, which is connected with still incomplete data on comparative material from other neighboring regions. Communities were found both in the southern part of the forest zone on flat relief of river terraces on sandy soils, and in the forest-steppe zone, where they are confined to the most elevated areas of the eroded relief and south-facing steep slopes. The terrace and ravine types are separated by soil conditions and not being adjacent to each other bordering the vegetation of other types meadow-steppes, broad-leaved forests, scrub vegetation and xeric pine forests. Soil reaction and climate continentality were identified as the main contributors to the floristic differentiation of the studied vegetation.The syntaxa of dry-mesic oak forests from the central and eastern parts of Ukraine cannot be placed in any of known alliances in the class Quercetea pubescentis. In contrast to subMediterranean type which is considered a class of zonal vegetation, in the remote northern part of the range of the class these communities occupy azonal habitats and descend to river terraces. As a whole, it is obvious that dry-mesic forests require a larger syntaxonomic revision in the eastern regions of Ukraine, Russia and Belarus. 


\section{Electronical supplementary material}

Table S1. Table of relevés (available at https://www.upjs.sk/pracoviska/botanicka-zahrada/ odborne-aktivity/volume-29-2019-abstracts/)

\section{References}

Bajrak O. M. (1996): The syntaxonomy of broad-leaved forests of the Left-Bank Dnieper Area. - Ukrainian phytosociological collection, Ser. A. 3: 51-64. [In Ukrainian]

Bajrak O. M. (1997): The syntaxonomy of pine forests of Left-Bank Dnieper and participation in that communities of epigeic lichens. - Ukrainian phytosociological collection, Ser. A. 6: 85-92. [In Ukrainian]

Bradis E. M. (1971): Vegetation of the Ukrainian SSR. Forests. - Naukova dumka, Kyiv, 460 pp. [In Ukrainian]

Bruelheide H. (2000): A new measure of fidelity and its application to defining species groups. - J. Veg. Sci. 11(2): 167-178. DOI: 10.2307/3236796

Bulokhov A. D. \& Semenishchenkov Yu. A. (2013): Botanical-geographical peculiarities of xeromesophytic broad-leaved forests of the alliance of Quercion petraeae Zólyomi et Jakucs ex Jakucs 1960 of the Southern Nechernozemie Region of Russia. - Bulletin of Bryansk Department of RBS 1(1): 10-24. [In Russian]

Čarni A., Košir P., Karadžić B., Matevski V., Redžić S. \& Škvorc Ž. (2009): Thermophilous deciduous forests in Southeastern Europe. - Plant Biosyst. 143(1): 1-13. DOI: $10.1080 / 11263500802633881$

Chytrý M. (1997): Thermophilous oak forests in the Czech Republic: Syntaxonomical revision of the Quercetalia pubescenti-petraeae. - Folia Geobot. Phytotax. 32(3): 221-258. DOI: 10.1007/BF02804006

Chytrý M. \& Horák J. (1997): Plant communities of the thermophilous oak forests in Moravia. - Preslia 68(3): 193-240.

Chytrý M., Tichý L., Holt J. \& Botta-Dukát Z. (2002): Determination of diagnostic species with statistical fidelity measures. - J. Veg. Sci. 13(1): 79-90. DOI: 10.1111/j.16541103.2002.tb02025.x

De Cáceres M., Font X. \& Oliva F. (2008): Assessing species diagnostic value in large data sets: A comparison between phi-coefficient and Ochiai index. - J. Veg. Sci. 19(6): 779-788. DOI: 10.3170/2008-8-18446

De Cáceres M. \& Legendre P. (2009): Associations between species and groups of sites: indices and statistical inference. - Ecology 90(12): 3566-3574. DOI: 10.1890/081823.1

Didukh Ya. P. (2011): The ecological scales for the species of Ukrainian flora and their use in synphytoindication. - Phytosociocentre, Kyiv, 176 pp.

Faliński J. B. \& Falińska K. (1986): Vegetation dynamics in temperate lowland primeval forests: ecological studies in Białowieża Forest. - Dr. W. Junk; Distributors for the U.S. and Canada, Kluwer Academic Publishers, Dordrecht; Boston: Hingham, MA, $537 \mathrm{pp}$.

Goncharenko I. V. (2003): Analysis of the plant cover of north-east Forest-Steppe of Ukraine. - Ukrainian Phytosociological Collection, Ser. A 19(1): 1-204. [In Ukrainian]

Goncharenko I. V. (2015a): A method of "sorting" clustering (DRSA) for the classification of plant communities. - Reports of the National Academy of Sciences of Ukraine (9): 129-136. 
Goncharenko I. V. (2015b): DRSA: a non-hierarchical clustering algorithm using k-NN graph and its application in vegetation classification. - Vegetation of Russia 27: 125-138. [In Russian]

Goncharenko I. V., Senchylo O. O. \& Didukh Ya. P. (2013): A method of quantitative evaluation of plant communities by their phytosociological spectra. - Chornomorsk. Bot. J. 9(4): 485-496. [In Ukrainian]

Greenj F. (1940): New finds and growth conditions of Veronica umbrosa M.B. on the Donetsk Ridge. - Botanical Journal of Academy of Sciences of Ukrainian SSR 1(2): 281-295. [In Ukrainian]

Hill M. O. \& Gauch H. G. (1980): Detrended correspondence analysis: An improved ordination technique. - Vegetatio 42(1-3): 47-58. DOI: 10.1007/BF00048870

Horváth A., Kevey B., Lendvai G., Simon G. \& Sonnevend I. (2017): Tatárjuharos-tölgyesek (Aceri tatarici-Quercetum pubescentis-roboris Zólyomi 1957) az Eszak-Mezőföldön és a Zámolyi-medence környékén. - Bot. Közlem. 104(1): 109-130. DOI: 10.17716/ BotKozlem.2017.104.1.109 [In Hungarian]

Indreica A. (2011): On the occurence in Romania of Potentillo albae-Quercetum petraeae Libbert 1933 association. - Not. Bot. Hort. Agrobot. Cluj-Napoca 39(1): 297-306. DOI: $10.15835 /$ nbha3915452

Jakubowska-Gabara J. (2000): Zbiorowiska leśne powstałe w wyniku przemian zespołu 3 Potentillo albae-Quercetum Libb. 1933 w Polsce. - Acta Univ. Lodz., Folia Bot. 15: 3-47.

Kasprowicz M. (2010): Acidophilous oak forests of the Wielkopolska region (West Poland) against the background of Central Europe. - Biodiv. Res.Conserv. 20(1): 1-212. DOI: 10.2478/v10119-010-0012-4

Kotov M. I. \& Karnaukh E. D. (1940): Vegetation of Reserves in the Stalin Region. Botanical Journal of Academy of Sciences of Ukrainian SSR 1(3-4): 335-352. [In Ukrainian]

Kottek M., Grieser J., Beck C., Rudolf B. \& Rubel F. (2006): World Map of the Köppen-Geiger climate classification updated. - Meteorol. Z. 15(3): 259-263. DOI: 10.1127/09412948/2006/0130

Lendvai G., Horváth A. \& Kevey B. (2014): Tatárjuharos tölgyesek (Aceri tatariciQuercetum pubescentis-roboris Zólyomi 1957) a Mezőföldön. - Bot. Közlem. 101(12): 145-188. [In Hungarian]

Libbert W. (1933): Die Vegetationseinheiten der neumärkischen Staubeckenlandschaft unter Berücksichtigung der angrenzenden Landschaften. - Verh. Bot. Ver. Prov. Brandenburg 75: 229-348. [In German]

Martynenko V. B., Shirokikh P. S., Muldashev A. A. \& Solomeshch A. I. (2008): New association of steppic oak forests in the Southern Urals. - Rastitelnost Rossii 13: 49-60. [In Russian]

Matuszkiewicz W. (2007): Przewodnik do oznaczanice zbiorowisk roslinnuch Polski. Wydawnictwo naukowe PWN, Warszawa, 537 pp. [In Polish]

Meusel H., Jäger E. J. \& Weinert E. (1965): Vergleichende Chorologie der Zentraleuropäischen Flora. - Gustav Fischer Verlag, Jena.

Mirkin B. M., Martynenko V. B., Bayesheva E. Z., Muldashev A. A., Sultangareyeva L. A., Urbanwichius G. P., Urbanavichene I. N., Shirokikh P. S., Yakupov I. I. \& Yamalov S. M. (2010): Flora and vegetation of the National Park "Bashkiria." - Gilem, Ufa, 512 pp. [In Russian]

Moravec J. (1973): Some notes on estimation of the basic homoteneity-coefficient of sets of phytosociological relevés. - Folia Geobot. Phytotax. 8(4): 429-434. DOI: 10.1007/BF02852068 
Mucina L., Grabherr G. \& Wallnöfer S. (1993): Die Pflanzengesellschaften Österreichs. Wälder und Gebüsche. - Gustav Fischer Verlag, Jena, 353 pp. [In German]

Mucina L., Bültmann H., Dierßen K., Theurillat J.-P., Raus T., Carni A., Šumberová K., Willner W., Dengler J., García R. G., Chytrý M., Hájek M., Di Pietro R., lakushenko D., Pallas J., Daniëls F. J. A., Bergmeier E., Santos Guerra A., Ermakov N., Valachovič M., Schaminée J. H. J., Lysenko T., Didukh Y. P., Pignatti S., Rodwell J. S., Capelo J., Weber H. E., Solomeshch A., Dimopoulos P., Aguiar C., Hennekens S. M. \& Tichý L. (2016): Vegetation of Europe: hierarchical floristic classification system of vascular plant, bryophyte, lichen, and algal communities R. Peet [ed.]. - Appl. Veg. Sci. 19: 3-264. DOI: 10.1111/avsc.12257

Nazarenko N. M. \& Kuzemko A. A. (2011): Syntaxa of vegetation of deciduous forests of the Northern Steppe of Ukraine. - Scientific reports of the National university of life and environmental sciences of Ukraine (2): 24. URL: http://www.nbuv.gov.ua/ejournals/Nd/2011_2/11nnm.pdf [Accessed March 22, 2019]

Oberdorfer E. (1992): Süddeutsche Pflanzengesellschaften. Wälder und Gebüsche. 2. Auflage. - G. Fischer, Jena, Stuttgart, New York, 288 pp. [In German]

Oksanen J., Blanchet F. G., Friendly M., Kindt R., Legendre P., McGlinn D., Minchin P. R., O’Hara R. B., Simpson G. L., Solymos P., Stevens M. H. H., Szoecs E. \& Wagner H. (2018): Package „vegan“: Community Ecology Package. R package version 2.4-6. URL: https://CRAN.R-project.org/package=vegan [Accessed September 21, 2018]

Onyshchenko V. A. (2009): Forests of order Fagetalia sylvaticae in Ukraine. - Alterpress, Kyiv, 212 pp.

Osadchy V. I., Kosovets O. O. \& Babichenko V. M. (2010): Climate of Kiev. - Nika Center, Kyiv, 320 pp. [In Ukrainian]

Panchenko S. M. (2013): Forest vegetation of the Desna-Starogutsk National Nature Park. - University Books Press, Sumy, 312 pp. [In Ukrainian]

Purger D., Lengyel A., Kevey B., Lendvai G., Horváth A., Tomić Z. \& Csiky J. (2014): Numerical classification of oak forests on loess in Hungary, Croatia and Serbia. Preslia 86(1): 47-66.

Roleček J. (2004): Subkontinentální doubravy asociace Carici fritschii-Quercetum roboris na Záhoří. - Bull. Slov. Bot. Spoločn. 26: 163-176.

Roleček J. (2005): Vegetation types of dry-mesic oak forests in Slovakia. - Preslia 77(3): 241-261.

Roleček J. (2007): Formalized classification of thermophilous oak forests in the Czech Republic: what brings the Cocktail method? - Preslia 79(1): 1-21.

Semenishchenkov Yu. A. (2012): Discussive questions of syntaxonomy of xeromesophytic deciduous forests of the South-Western Nechernozemie Region of Russia. - Izvestia of Samara Scientific Center of the Russian Academy of Sciences 14(4): 1117-1120. [In Russian]

Shevchyk V. L., Solomakha V. A. \& Voityuk Yu. O. (1996): Syntaxonomy of vegetation and list of flora of the Kaniv Nature Reserve. - Ukrainian phytocoenological collection, Ser. B. 4(1): 1-119. [In Ukrainian]

Solomakha I. V., Senchylo O. O. \& Vorobyov Ye. O. (1996): Forest vegetation of the "Zhukiv Khutir" tract. - Ukrainian Phytosociological Collection, Ser. A 3: 63-78. [In Ukrainian]

Stupar V., Milanović Đ., Brujić J. \& Čarni A. (2015): Formalized classification and nomenclatural revision of thermophilous deciduous forests (Quercetalia pubescentis) of Bosnia and Herzegovina. - Tuexenia 35: 85-130. DOI: 10.14471/2015.35.016

Sudnik-Wójcikowska B. (1991): Synantropization indices of urban floras: an attempt at definition and assessment. - Acta Soc. Bot. Pol. 60(1-2): 163-185. 
Tzonev R. T., Dimitrov M. A. \& Roussakova V. H. (2009): Syntaxa according to the BraunBlanquet approach in Bulgaria. - Phytol. Balcan. 15(2): 209-233.

Vorobyov Ye. O., Smoliar N. O., Smagliuk O. Yu. \& Solomakha I. V. (2017): The new association of xeromesophytic oak forests of Aceri tatarici-Quercion roboris alliance (class Quercetea pubescentis) in the basin of Lower Sula. - Chornomorsk. Bot. J. 13(3): 295-305. DOI: 10.14255/2308-9628/17.133/4 [In Ukrainian]

Willner W., Solomeshch A., Čarni A., Bergmeier E., Ermakov N. \& Mucina L. (2016): Description and validation of some European forest syntaxa - a supplement to the EuroVegChecklist. - Hacquetia 15(1): 15-25.

Zólyomi B. (1957): Der Tatarenahorn-Eichen-Lösswald der zonalen Waldsteppe. - Acta Bot. Acad. Sci. Hung. (3): 401-424.

Zólyomi B., Horváth A., Kevey B. \& Lendvai G. (2013): Steppe woodlands with Tatarian Maple (Aceri tatarici-Quercetum pubescentis-roboris) on the great Hungarian plain and its neighborhood. An unfinished synthesis with supplementary notes. - Acta Bot. Hung. 55(1-2): 167-189. DOI: 10.1556/ABot.55.2013.1-2.11 